https://helda.helsinki.fi

\title{
The relevance of researching video games and cultural heritage
}

\section{Zeiler, Xenia}

2021-03-04

Zeiler , X \& Thomas , S 2021, ' The relevance of researching video games and cultural heritage ' , International Journal of Heritage Studies , vol. 27 , no. 3 , pp. 265-267 . https://doi.org/10.1080/13527258

http://hdl.handle.net/10138/335971

https://doi.org/10.1080/13527258.2020.1762705

cc_by_nc

acceptedVersion

Downloaded from Helda, University of Helsinki institutional repository.

This is an electronic reprint of the original article.

This reprint may differ from the original in pagination and typographic detail.

Please cite the original version. 
Xenia Zeiler \& Suzie Thomas (2020): The relevance of researching video games and cultural heritage, International Journal of Heritage Studies, DOI:10.1080/13527258.2020.1762705

\section{ABSTRACT}

This is the introduction to the special issue on video games and cultural heritage.

\section{KEYWORDS}

Video games; cultural heritage; games research; digital heritage; digital culture

Video games are already recognised as a component of the increasingly diverse ways in which we frame and consider the concept of 'heritage' - though so far, scholars have most often discussed and critiqued the depiction of history (as cultural heritage) in video games themselves (e.g. Cassone 2016; Copplestone 2017; Reinhard 2018). Also, certain triple A games (the term used for high budget games produced and distributed by major companies and publishers) already attracted a large amount of scholarly research in relation to their use of imagery of the past, for example, Assassin's Creed (e.g. Hammar 2017; Shaw 2015), and Call of Duty (e.g. Gish 2010; Pötzsch and Šisler 2019). This has included sharp critique of historical inaccuracies, sometimes paired with conceptions of video games as platforms that can challenge 'historical authority' (e.g. Salvati and Bullinger 2013), through to the exploration of the potential of video games as a medium through which to present research (namely, on history) itself. An example of this is Spring's (2015) imagining of video games as a viable and more accessible alternative to monographs for presenting historical research as a 'scholarly game', taking advantage of the flexibility and multilayeredness of the format.

Heritage understood in a broader sense and as including elements beyond history, such as specific art forms, Indigenous heritage and so forth, and video games has attracted much less attention so far (see, e.g. Barwick, Dearnley, and Muir 2011; Zeiler 2020). For example, the potential of indie games (produced and distributed by smaller companies and individuals) co-produced with Indigenous communities in this field (see Campbell and Grieve 2014; Radde-Antweiler, Waltemathe, and Zeiler 2014).

At the same time, video games are not only understood as platforms through which users can consume representations of heritage and cultural identity, but also as a form of heritage in their own right (Barwick, Dearnley, and Muir 2011). This is true on one level in the appearance of museums devoted to collecting, curating and exhibiting video games over time - such as the National Videogame Museum in Sheffield, UK, the Computerspielemuseum in Berlin, Germany, the Museum of Art and Digital Entertainment in Oakland, USA, and the Finnish Museum of Games in Tampere. Such collections, of course, move beyond the alreadycommon incorporation of gamified 'interactives' as an interpretational tool for presenting museum content to audiences within exhibition spaces and online, to the consideration of video games themselves as worthy of preservation and documentation. Nylund, Prax and Sotamaa in this special issue contribute to the debate of how best to preserve and interpret video games in a museological context, adding to discussions from fields as diverse as law (Corbett 2007), media and communication studies (Stuckey et al. 2015), and from within game studies itself (e.g. Navarro-Remesal 2017).

All of these examples lead towards the precise point at which we situate our special issue: We present research on a number of examples which demonstrate the complex interrelation of video games and cultural heritage. That is, instead of solely focusing on expressions of (elements of) cultural heritage in games, we emphasise that cultural heritage is related to games in much more complex ways. Games have become powerful tools for negotiating Indigenous heritage - not only via game immanent narrations and aesthetics (see LaPensée), but also via gaming and activities around games and gaming, e.g. in game jams 
(see Laiti et al.). Additionally, this special issue acknowledges the complexity of what constitutes cultural heritage and video games, to begin with. For example, expressions and representations of many cultural and social fields may be understood as cultural heritage, such as religion (see De Wildt and Aupers), and games themselves are part of cultural heritage (see Nylund, Prax and Sotamaa).

The issue's opening article 'Rethinking Game Heritage: Towards Reflexivity in Game Preservation' by Niklas Nylund, Patrick Prax and Olli Sotamaa argues that most video game exhibitions are based on a limited understanding of games that relies on symbolic brands, on the one hand, and on the centrality of playable experiences on the other. This bias is potentially replicated by heritage institution collections starting to define how games become cultural heritage.

By connecting previous work on critical and intangible heritage with game studies literature, this article emphasises the importance of various productive communities for game heritage. The concepts of intangible and critical heritage suggest that the inclusion of players and communities into the game heritage process could offer a more diverse heritage discourse.

Elizabeth LaPensée in 'When Rivers Were Trails: Cultural expression in an Indigenous video game' discusses the game in question, which depicts various cultures during the player's journey from Minnesota to California amidst the impact of land allotment in the 1890s, through an Indigenous lens. Merging design research and close reading methods, this study sets out to describe the game's design, development process in regard to the game writing, and the resulting themes which emerged as a result of engaging Indigenous writers in self-determined representations.

In 'Sustaining intangible heritage through video game storytelling: The case of the Sami Game Jam', Outi Laiti, Sabine Harrer, Satu Uusiautti and Annakaisa Kultima explore how game jamming as a cultural practice can be appropriated for the purpose of sustaining intangible cultural heritage, namely, how game jams can support the revitalisation of Indigenous self-narratives in the context of Sámi culture. The article discusses how the creation of Sámi themes and priorities created constraints for game design; the collaborative game development to explore current Sámi experience in a dialogic, open-ended way; and how the design of the newly created games translate Sámi themes into playable artefacts.

In the special issue's final article 'The flattening of religious cultural heritage in video games', Lars De Wildt and S. D. Aupers argue that in the West, religious icons and representations increasingly appear as cultural heritage rather than active subjects of religious practice. This article studies Japanese video games, using the Final Fantasy series as a case study, to ask: Which religions, folklores, cultures and their divinities are represented in video games, and how? What are the implications for including them?

We thank the authors of these diverse and engaging papers for their work and their participation in this special issue. Through this collection of papers, we aim to deepen the research of the interplay between video games and cultural heritage, and potentially to introduce video games as a rich vein of study and reflection to a wider heritage studies community.

\section{Acknowledgments}

We would like to acknowledge the Helsinki Future Fund, which funded the initial project 'Digital Educational Tool Development: Durga Puja and Museums', from which the idea for this special issue sprang.

\section{Disclosure statement}

No potential conflict of interest was reported by the authors.

\section{Funding}


This work was supported by the Helsinki Future Fund.

\section{Notes on contributors}

Xenia Zeiler is Associate Professor of South Asian Studies at the University of Helsinki, Finland. Her research focuses on digital media (especially video games) and culture, including cultural heritage, especially in India and the global Indian community.

Suzie Thomas is Associate Professor of Cultural Heritage Studies at the University of Helsinki, Finland. She holds a PhD from Newcastle University, UK, and is responsible for the Cultural Heritage Studies minor study track in Helsinki. She is interested in non-professional and alternative engagements with cultural heritage.

\section{ORCID}

Xenia Zeiler http://orcid.org/0000-0003-4214-0688

Suzie Thomas http://orcid.org/0000-0002-3365-0136

\section{References}

Barwick, J., J. Dearnley, and A. Muir. 2011. "Playing Games with Cultural Heritage: A Comparative Case Study Analysis of the Current Status of Digital Game Preservation." Games and Culture 6 (4): 373-390. doi:10.1177/1555412010391092.

Campbell, H., and G. P. Grieve, eds. 2014. Playing with Religion in Digital Games. Bloomington: Indiana University Press. Cassone, V. I. 2016. "The HGR Framework: A Semiotic Approach to the Representation of History in Digital Games." gamevironments 5: 156-204.

Copplestone, T. J. 2017. "But That's Not Accurate: The Differing Perceptions of Accuracy in Cultural-heritage Videogames between Creators, Consumers and Critics." Rethinking History 21 (3): 415-438. doi:10.1080/13642529.2017.1256615.

Corbett, S. 2007. "Digital Heritage: Legal Barriers to Conserving New Zealand's Early Video Games." New Zealand Business Law Quarterly 13 (5): 48-71.

Gish, H. 2010. "Playing the Second World War: Call of Duty and the Telling of History." Eludamos. Journal for Computer Game Culture 4 (2): 167-180.

Hammar, E. L. 2017. "Counter-hegemonic Commemorative Play: Marginalized Pasts and the Politics of Memory in the Digital Game Assassin's Creed: Freedom Cry." Rethinking History 21 (3): 372-395. doi:10.1080/13642529.2016.1256622.

Navarro-Remesal, V. 2017. "Museums of Failure: Fans as Curators of "Bad", Unreleased, and "Flopped" Videogames 1." In Fans and Videogames: Videos, Fandoms, Archives, edited by M. Swalwell, A. Ndalianis, and H. Stuckey, 128-145. New York: Routledge.

Pötzsch, H., and V. Šisler. 2019. "Playing Cultural Memory: Framing History in Call of Duty: Black Ops and Czechoslovakia 38-89: Assassination." Games and Culture 14 (1): 3-25. doi:10.1177/1555412016638603.

Radde-Antweiler, K., M. Waltemathe, and X. Zeiler. 2014. "Video Gaming, Let's Plays and Religion: The Relevance of Researching gamevironments." gamevironments 1: 1-36.

Reinhard, A. 2018. Archaeogaming: An Introduction to Archaeology in and of Video Games. New York: Berghahn Books. 
Salvati, A. J., and J. M. Bullinger. 2013. "Selective Authenticity and the Playable Past." In Playing with the Past: Digital Games and the Simulation of History, edited by M. W. Kapell and A. B. R. Elliott, 153-167. New York: Bloomsbury.

Shaw, A. 2015. "The Tyranny of Realism: Historical Accuracy and Politics of Representation in Assassin's Creed III." Loading... 9: 14.

Spring, D. 2015. "Gaming History: Computer and Video Games as Historical Scholarship." Rethinking History 19 (2): 207-221. doi:10.1080/13642529.2014.973714.

Stuckey, H., M. Swalwell, A. Ndalianis, and D. De Vries. 2015. "Remembering \& Exhibiting Games Past: The Popular Memory Archive." Transactions of the Digital Games Research Association 2 (1): 9-35. doi:10.26503/todigra.v2i1.40.

Zeiler, X. 2020. "Digital Humanities Practices and Cultural Heritage. Indian Video Games." In Exploring Digital Humanities in India, edited by M. Dodd and N. Kalra. New York: Routledge. (in press). 